\title{
PENGEMBANGAN BAHAN AJAR ONLINE SEBAGAI MEDIA PEMBELAJARAN SELAMA COVID-19
}

\author{
Rozana Afriani ${ }^{1 *}$, Muti'ah ${ }^{2}$, Syarifa Wahidah Al Idrus ${ }^{3}$ \\ 123 Program Studi Pendidikan Kimia, FKIP, Universitas Mataram. Jalan Majapahit No. 62 \\ Mataram, NTB 83112, Indonesia. \\ * Coressponding Author: rozanaafriani10@ gmail.com
}

Received: 21 Mei 2021

Accepted: 13 Agustus 2021

Published: 14 Agustus 2021

doi: 10.29303/cep.v4i2.2672

\begin{abstract}
Abstrak
Penelitian ini termasuk penelitian pengembangan $(R \& D)$ yang bertujuan untuk mengetahui tingkat kelayakan dan kepraktisan dari bahan ajar online yang dikembangkan. Bahan ajar online dengan pokok bahasan hukum-hukum dasar kimia untuk pegangan peserta didik kelas $\mathrm{X}$ telah berhasil dikembangkan. Populasi penelitian sebanyak 164 peserta didik dengan jumlah sampel 64 peserta didik kelas X IPA 1 dan X IPA 2 SMA Negeri 5 Mataram dengan tenik non probability sampling secara purposive sampling. Pengembangan bahan ajar online telah melalui serangkaian tahapan validasi ahli, respon guru dan peserta didik menggunakan instrument angket, dan uji coba terbatas. Penelitian pengembangan $(R \& D)$ dilakukan dengan 4 tahapan yakni: tahap define (pendefinisian), tahap design (perancangan), tahap development (pengembangan), dan tahap dissemination (penyebaran). Bahan ajar online yang telah dikembangkan dinyatakan sangat layak oleh validator ditinjau dari beberapa komponen dengan nilai rata-rata didapatkan sebesar 0.85 dari skor 80-100 dan praktis dengan persentase kepraktisan dari peserta didik sebesar 79\% serta didukung dengan persentase kepraktisan dari guru sebesar $88 \%$. Berdasarkan hasil yang diperoleh dapat ditarik kesimpulan bahwa bahan ajar online dengan pokok bahasan hukum-hukum dasar kimia kelas $\mathrm{X}$ yang telah dikembangkan dengan model 4D memenuhi kriteria yakni sangat layak dan sangat praktis digunakan dalam proses kegiatan belajar mengajar secara online.
\end{abstract}

Kata Kunci: pengembangan, bahan ajar online, hukum-hukum dasar kimia

\section{Development of Online Teaching Materials as A Learning Media During Covid-19}

\begin{abstract}
This research includes development research $(R \& D)$ which aims to determine the feasibility and practicality of the developed online teaching materials. Online teaching materials with the subject of basic laws of chemistry for grade $X$ students have been successfully developed. The study population was 164 students with a total sample of 64 students in class X IPA 1 and X IPA 2 SMA Negeri 5 Mataram with a non-probability sampling technique using purposive sampling. The development of online teaching materials has gone through a series of expert validation stages, the response of teachers and students using a questionnaire instrument, and limited trials. The development research $(R \& D)$ is carried out in 4 stages, namely: the define stage, the design stage, the development stage, and the dissemination stage. The online teaching materials that have been developed are stated to be very feasible by the validator in terms of several components with an average value of 0.85 from a score of 80-100 and practical with a practical percentage of students of $79 \%$ and supported by a practical percentage of the teacher of $88 \%$. Based on the results obtained, it can be concluded that online teaching materials with the subject of the basic laws of chemistry class $X$ that have been developed with the 4D model meet the criteria, namely very feasible and very practical to use in the process of teaching and learning activities online.
\end{abstract}

Keywords: development, online teaching materials, basic chemical law 


\section{Chemistry Education Practice, 4 (2), 2021 - 202}

Afriani, Muti'ah, Al Idrus

\section{PENDAHULUAN}

Pandemi adalah suatu musibah yang dapat memberikan dampak kekhawatiran terhadap kehidupan di bumi. Indonesia, dampak dari penyebaran covid-19 telah merubah seluruh tatanan kehidupan baik dari segi sosial, ekonomi, budaya maupun pendidikan (Aji, 2020). Kasus penyebaran covid-19 yang sangat signifikan per tanggal 10 April 2020 sebesar $8.7 \%$. Indonesia berada pada urutan keempat tertinggi tingkat penyebaran covid-19 setelah Italia, Perancis, dan Spanyol (Siagian, 2020). Tingginya tingkat kasus penyebaran covid-19, telah mendesak pemerintah mengambil keputusan untuk menutup sekolah guna menghindari kontak fisik secara langsung (physical distancing) (Aji, 2020).

Di wilayah Nusa Tenggara Barat (NTB) sendiri, kasus penyebaran covid-19 cukup tinggi dengan persentase sebesar $5.90 \%$ (Yuniati, 2020). Hal ini mengharuskan pemerintah untuk menutup sementara seluruh aktivitas baik di tempat umum, kantor, pusat perbelanjaan maupun di ruang lingkup pendidikan. Adapun dampak dari ditutupnya sekolah yakni: (1) proses pembelajaran dilaksanakan di rumah peserta didik, (2) proses pembelajaran kurang efektif, dan (3) acuan yang tidak memadai. Adapun solusi dalam menangani hal tersebut yakni media pembelajaran online. (Aji, 2020).

Media pembelajaran online adalah media yang didukunng dengan berbagai kelengkapan seperti alat pengontrol yang bisa diaplikasikan, dikendalikan dan diakses sesuai dengan kebutuhan pengguna. Penggunaan media pembelajaran online dalam masa pandemi sangatlah tepat karena berfungsi sebagai memudahkan peserta didik dalam hal kegiatan belajar mengajar, salah satunya melalui platform daring. Platform daring merupakan suatu program yang dapat digunakan dalam mengerjakan suatu rencana kerja yang berfungsi sebagai wadah utama dalam mengoperasikan suatu sistem dengan sebaik mungkin. Dalam masa pandemi penggunaan platform daring sangatlah tepat bagi peserta didik dalam memudahkan proses kegiatan belajar mengajar. Berbagai jenis platform daring yang umum digunakan di sekolah seperti whatsApp, google classroom, moodle dan lain sebagainya (Fitria, 2020).

Potensi pemanfaatan platform daring di setiap sekolah di seluruh Indonesia memiliki potensi yang cukup besar dalam mempermudah proses kegiatan belajar mengajar. Platform daring dapat diterapkan di salah satu sekolah yakni SMAN 5 Mataram. Hal ini menunjukkan bahwa keterbukaan dari pihak sekolah dalam memberikan informasi terkait kegiatan penelitian. Selain itu, memudahkan peneliti dalam memilih dan menentukan pokok bahasan yang telah dikembangkan dalam media pembelajaran online serta sebagai acuan proses kegiatan belajar. Adapun pokok bahasan yang dapat dikembangkan karena kesulitan bagi peserta didik dalam mempelajari dan memahami pokok bahasan tersebut sehingga membutuhkan suatu pengembangan bahan ajar online.

Hukum-hukum dasar kimia merupakan suatu karakteristik konsep dalam kegiatan pembelajaran yang bersifat konkrit dan abstrak. Pembelajaran yang bersifat konkrit diartiakan sebagai suatu sistem pembelajaran yang dilakukan secara nyata dan melalui kegiatan eksperimen oleh peserta didik. Sedangkan pembelajaran yang bersifat abstrak diartikan sebagai suatu sistem pembelajaran dengan metode berfikir secara abstrak yang dilakukan oleh peserta didik dengan tujuan untuk memperoleh pemahaman denagan cara pengamatan terhadap data-data hasil eksperimen. Sehingga peserta didik dapat menguasai konsep dan dapat menyimpulkan pengetahuan dari pokok bahasan tersebut. (Sari, 2014).

Dari pemaparan tersebut, maka telah dilakukan penelitian terkait "Pengembangan bahan ajar online sebagai media pembelajaran selama covid-19 pada peserta didik dengan pokok bahasan hukum-hukum dasar kimia kelas X di SMAN 5 Mataram.”

\section{METODE}

Penelitian dilaksanakan dari bulan JuliFebruari di SMAN 5 Mataram. Jalan udayana No.2A, Mataram Barat, Kecamatan Selaparang, Kota Mataram, Nusa Tenggara Barat. Jenis penelitian pengembangan (research and development) model 4D yang dinyatakan oleh Thiagarajan.

Tahap pendefinisian (define) bertujuan untuk menjelaskan dan membatasi beberapa yang menjadi ruang lingkup dalam pengembangan yang terdiri dari 4 langkah antara lain analisis awal-akhir, analisis materi, analisis tugas, dan spesifikasi tujuan pembelajaran (Mujiyanti, 2020). Tahap perancangan (design) bertujuan untuk membuat rancangan perangkat pembelajaran dengan tahapan pemilihan media 
dan format, serta rancangan awal (Rahmawati, 2021). Tahap pengembangan (develop) bertujuan untuk memproduksi produk berupa bahan ajar online yang layak dan praktis (draft I) kemudian memperoleh (draft II) dengan menggunakan instrumen penelitian lembar validasi dan angket respon peserta didik dan guru (Adawiyah, 2020). Tahap penyebaran (disseminate) bertujuan untuk melaksanakan sosialisasi kepada guru dan peserta didik melalui platform daring terhadap bahan ajar online yang sudah divalidasi dan diuji coba pada responden (Safitri, 2020).

Populasi dalam penelitian ialah peserta didik kelas X SMAN 5 Mataram yang terdiri dari lima kelas dengan jumlah 164. Jumlah populasi yang digunakan sebagai sampel sebanyak 64 peserta didik. Pengumpulan data menggunakan instrumen validitas ahli untuk uji kelayakkan dimana hasil validasi dianalisis dengan indeks validitas sedangkan angket untuk uji kepraktissan dalam penilaian produk dengan skala Likert (Irsalina, 2018).

\section{HASIL DAN PEMBAHASAN}

\section{Pengembangan bahan ajar online}

Tahap awal yang dilakukan ialah analisis awal-akhir, materi, tugas, dan spesifikasi tujuan pembelajaran. Analisis dilakukan terhadap silabus, rencana pelaksanaan pembelajaran (RPP), dan pengumpulan beberapa literature dan menentukan batasan dalam pokok bahasan hukum-hukum dasar kimia sehingga dapat ditarik kesimpulan untuk menentukan kemampuan akhir, bahan kajian, dan indikator pencapaian kompetensi, dengan demikian bahan ajar online yang dikembangkan dapat digunakan dalam pokok bahasan hukum-hukum dasar kimia dengan 1 kali pertemuan dalam kegiatan belajar mengajar.

Penyusunan bahan ajar online sebagai draft I diawali dengan perancangan sampul bahan ajar online, komponen bahan ajar online, antara lain: (1) kata pengantar, peta konsep, petunjuk bahan ajar online, kompetensi dasar (KD), indikator pencapaian kompetensi (IPK), dan tujan pembelajaran; (2) materi terkait, contoh soal dan latihan soal; (3) lembar kerja peserta didik (LKPD) yang berisi judul, identitas peserta didik, petunjuk, tujuan pembelajaran, materi terkait, dan kegiatan peserta didik. Uji kelayakkan menggunakan instrumen lembar validasi ahli dan dianalisis dengan indeks validitas yang termasuk dalam kategori sangat layak serta dapat diproduksi setelah melakukan revisi ( draft II).

Bahan ajar online (draft II) diuji kepraktisannya kepada guru dan peserta didik kelas X di SMAN 5 Mataram. Uji kepraktisan yang dilakukan uji coba terbatas pada guru dan peserta didik yang bertujuan untuk menghasilkan respon terhadap bahan ajar online. Angket terdiri dari 21 butir pernyataan yang terdiri dari 4 komponen. Setelah uji kevalidtan dan kepraktisan kemudian memberikan bahan ajar online kepada guru melalui platform daring sehingga nantinya peserta didik dapat menggunakan bahan ajar online tersebut sebagai refrensi atau acuan dalam kegiatan pembelajaran. Penyebaran bahan ajar online dengan pokok bahasan hukum-hukum dasar kimia bertujuan untuk memperkenalkan bahan ajar online yang sudah dikembangkan dan memenuhi kriteria sehingga dapat dipakai guru untuk kegiatan pembelajaran.

\section{Validitas bahan ajar online}

Validasi dilakukan oleh lima validator dari guru SMAN 5 Mataram dan SMAN 3 Mataram.

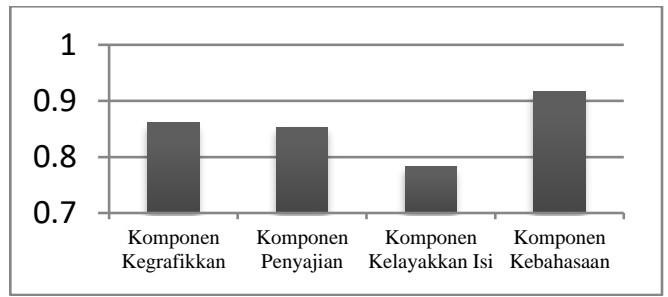

Gambar 1. Grafik kelayakkan bahan ajar online

Berdasarkan grafik kelayakkan dari uji validitas bahan ajar online yang bertujuan untuk mengetahui tingkat kelayakkan bahan ajar online dengan pokok bahasan hukum-hukum dasar kimia. Hasil analisis dari uji validitas berdasarkan 4 komponen validasi tersebut sehingga mendapatkan nilai rata-rata dari keseluruhan terhadap kelayakkan bahan ajar online sebesar 4 dari skor 1-4 dengan kategori sangat layak, artinya bahan ajar online tersebut mampu untuk meningkatkan keterampilan peserta didik dalam kegiatan pembelajaran yang diterapkan dan dapat digunakan untuk mengukur serta mengarahkan kegiatan proses pembelajaran peserta didik secara tepat dan sesuai (Rahmawati, 2021). Selain itu juga, dalam kegiatan pembelajaran yang dilakukan dengan bantuan bahan ajar berbasis web (online) dapat meningkatkan aktivitas peserta didik (Hidayatulah, 2015). Berdasarkan pemaparan tersebut dapat ditarik kesimpulan bahwa 
pengembangan bahan ajar online sebagai media pembelajaran selama covid-19 pada peserta didik dengan pokok bahasan hukum-hukum dasar kimia kelas X di SMAN 5 Mataram layak untuk digunakan sebagai salah satu sumber atau acuan dalam kegiatan pembelajaran online ( $e$ learning).

\section{Kepraktisan bahan ajar online}

Bahan ajar online yang telah dinyatakan layak kemudian dilakukan uji kepraktisan. Uji kepraktisan terdiri dari 4 komponen yang dilakukan kepada guru dan peserta didik kelas $\mathrm{X}$ di SMAN 5 Mataram. Uji kepraktisan berfungsi untuk mengetahui tingkat kepraktisan dari bahan ajar online yang telah dikembangkan. Hasil analisis dari uji kepraktisan disajikan sebagai berikut:

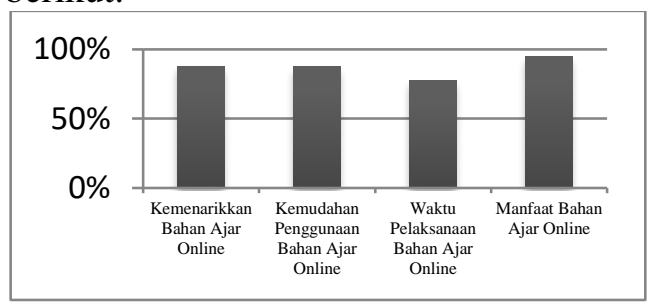

Gambar 2. Praktikalitas guru

Berdasarkan grafik di atas hasil analisis dari 4 komponen uji kepraktisan didapatkan nilai rata-rata sebesar $88 \%$ yang tergolong sangat praktis, artinya bahan ajar online dapat memudahkan pendidik dalam pemutahkiran (mengupgrade) bahan belajar yang sesuai dengan tuntutan perkembangan teknologi, meningkatkan wawasan dan keterampilan, serta mempermudah dalam menyampaikan materi pelajaran yang bersifat abstrak (Jazuli, 2017).

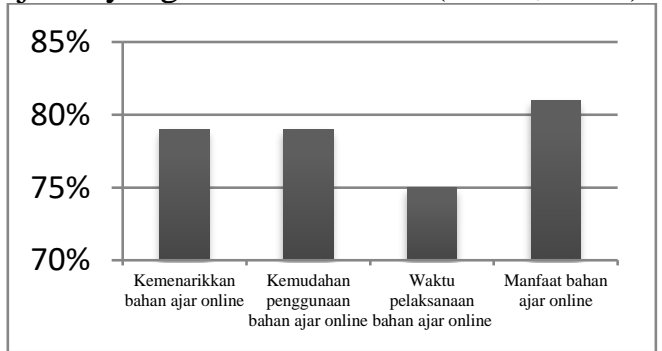

Gambar 3. Praktikalitas peserta didik

Berdasarkan grafik di atas dari hasil analisis dari 4 komponen uji kepraktisan didapatkan nilai rata-rata sbesar $79 \%$ yang tergolong praktis, artinya bahan ajar online memudahkan peserta didik dalam mengakses bahan belajar setiap saat dan secara berulang, membantu peserta didik yang berhalangan hadir untuk mengikuti pembelajran di kelas karena sakit, bepergian, dan sebagainya sehingga tetap dapat mengikuti, mempelajari, memahami, dan memantapkan penguasaannya terhadap materi pembelajaran oleh peserta didik (Jazuli, 2017).

\section{SIMPULAN}

Berdasarkan hasil penelitian dan pembahasan dapat disimpulkan bahwa bahan ajar online dengan pokok bahasan hukumhukum dasar kimia kelas X layak dan praktis untuk digunakan sebagai kegiatan pembelajaran oleh pendidik maupun peserta didik secara online (E-learning).

\section{DAFTAR PUSTAKA}

Adawiyah, S. R., Hakim. A., dan Hadisaputra.S., (2020). Pengembangan Modul Praktikum Kimia Bahan Alam Berbasis Generik Sains: Isolasi Fenobarbiton dari Kulit Batang Pohon Api (Avicennia Marina). Jurnal Chemistry Education Practice, Vol. 3, No. 2 hal: 84-90.

Aji, R. H. S., (2020). Dampak Covid-19 pada Pendidikan di Indonesia: Sekolah, Keterampilan, dan Proses Pembelajaran. Jurnal Sosial dan Budaya Syar-I, Vol. 7, No. 5 hal: 395-402.

Fitria, R.N., Darmadi., Pertiwi. W., Putri. M., Wardani., Wulandari. Y., Ervinda. E. I., dan Aysah., (2020). Tingkat Keaktifan Siswa dalam Pembelajaran Matematika Menggunakan E-Learning dan Platform Daring. Jurnal Review Pendidikan dan Pengajaran (JRPP), Vol. 3, No. 2 hal: 306-314.

Hidayatulah, A. H., Yushardi., dan Sri. W., (2015). Pengembangan Bahan Ajar Berbasis Web Interaktif dengan Aplikasi E- Learning Moodle pada Pokok Bahasan dan Satuan di SMA. Jurnal Pendidikan Fisika, Vol. 4, No. 2 hal: 111-115.

Irsalina, A., dan Dwiningsih. K., (2018). Analisis Kepraktisan Pengembangan Lembar Kegiatan Peserta Didik (LKPD) Berorientasi Blended Learning pada Materi Asam Basa. Jurnal Kimia dan Pendidikan Kimia (JKPK), Vol. 3, No. 3 hal: 171-182.

Jazuli, M., Azizah. L. F., dan Meita. N. M., (2017). Pengembangan Bahan Ajar Elektronik Berbasis Android sebagai Media Interaktif. Jurnal Lensa (Lentera Sains): Jurnal Pendidikan IPA, Vol. 7, No. 2 hal: 47-65.

Mujiyanti, A. R., Hakim. A., dan Hadisaputra.

S., (2020). Pengembangan Modul Praktikum Generik Sains Kimia Bahan 
Chemistry Education Practice, 4 (2), 2021 - 205

Afriani, Muti'ah, Al Idrus

Alam: Isolasi Asam Anakardat dari Kulit

Biji Jambu Mete. Jurnal Chemistry

Education Practice, Vol. 3, No. 2 hal: 91-

98.

Rahmawati., Laksmiwati. D., Idrus. S. W. A.,

Hakim. A., dan Supriadi., (2021).

Pengembangan Modul Praktikum Kimia

Organik I Berbasis Problem Based

Learning (PBL) dalam Meningkatkan

Keterampilan Sains. Jurnal Pijar MIPA,

Vol. 16, No. 2 hal: 176-179.

Safitri, A., Hakim. A., dan Sofia. B. F. D.,

(2020). Pengembangan Modul Praktikum

Kimia Bahan Alam Berbasis Generik

Sains: Isolasi Kafein dari Bubuk Kopi.

Jurnal Chemistry Education Practice, Vol.

3, No. 1 hal: 47-54.

Sari, P. A. W., Rudibyani. R. B., dan Sofiya. E., (2014). Efektivitas Discovery Learning dalam Meningkatkan Penguasaan Konsep dan Kemampuan Menyimpulkan. Jurnal Pendidikan Dan Pembelajaran Kimia (JPPK), Vol. 3, No. 2 hal: 1-14.

Siagian, T. H., (2020). Mencari Kelompok Berisiko Tinggi Terinfeksi Virus Corona Dengan Discourse Network Analysis. Jurnal Kebijakkan Kesehatan Indonesia (JKKI), Vol. 9, No. 2 hal: 98-106.

Thiagarajan, S., Ammel. D., dan Semmel. M. I., (1974). Instructional Development For Training Teachers Of Exceptional Children: A Source Book. Minnesota: University Of Minnesota.

Yuniati, M., dan Amini. R. (2020). Analisis Dampak Covid-19 terhadap Daya Beli Masyarakat NTB. Jurnal Penelitian Manajemen, Vol. 2, No. 2 hal: 362-368. 